\title{
CGMP-Dependent 3',5'-Cyclic Phosphodiesterase
}

National Cancer Institute

\section{Source}

National Cancer Institute. CGMP-Dependent 3',5'-Cyclic Phosphodiesterase. NCI

Thesaurus. Code C104742.

cGMP-dependent 3',5'-cyclic phosphodiesterase (941 aa, $106 \mathrm{kDa}$ ) is encoded by the human PDE2A gene. This protein is involved in the catabolism of both cyclic GMP and cyclic AMP. 